\title{
TÁRSASÁGI HÍREK
}

\author{
KOPECZKY RITA - KRUPP JÓZSEF - SIMON LAJOS ZOLTÁN
}

\section{BESZÁMOLÓ A 2014-15. TANÉVI ÁBEL JENŐ ORSZÁGOS LATIN TANULMÁNYI VERSENYRÖL}

Az Ókortudományi Társaság - az Emberi Erőforrások Minisztériuma támogatásával - a 2014/2015-ös tanévben is megrendezte, immár 51. alkalommal, országos, Ábel Jenőről elnevezett latin tanulmányi versenyét. A Minisztérium versenyünket a Nemzeti Tehetség Program keretében, az Emberi Erőforrás Támogatáskezelőn keresztül, az NTP-TV-14-A-0006 sz. pályázat révén támogatta.

A versenyről készült beszámoló előtt ezen a helyen emlékezünk meg róla, hogy az Arpinói Nemzetközi Cicero-verseny hazai válogatóján örvendetes módon számos kitűnő fordítás született. Még örvendetesebb, hogy a Németh László Gimnázium növendéke, Bánfay Ágota tanítványa, Frivaldszky Lőrinc az arpinói versenyen különdíjban részesült. A nagyszerű eredményhez mind a versenyzőnek, mind fölkészítő tanárának szívből gratulálunk. Biztató visszaigazolása az Ábel Jenő Országos Latin Tanulmányi Versenynek, hogy akik korábban - netán több ízben is - részt vettek rajta, a válogatón is jól szerepeltek.

Márpedig a versenyzőknek korántsem könnyű szöveggel (Cicero a retorikát tanulmányozó Aristotelésről, De inventione II. 6-7) kellett megbirkózniuk. A szöveg nehézségét fokozta, hogy az átlagos fordítási feladatoknál megszokott, összefüggő elbeszélésnél Cicero elméleti fejtegetése jóval kevesebb fogódzót nyújtott az alaktanban és a mondattanban kevésbé biztos versenyzőknek. A mondatelemzésben és a szótárazásban való gyakorlottság hiánya jól mérhető volt az utolsó mondaton: Nam fuit tempore eodem, quo Aristoteles, magnus et nobilis rhetor Isocrates; cuius ipsius quam constet esse artem non invenimus. A második tagmondat szerkezete nem egy esetben még azokon is kifogott, akik máskülönben egészen magas pontszámot értek el, olyannyira, hogy találgatásokba voltak kénytelenek bocsátkozni: „akinek magának a művészete - kétségtelenül - az, amit mi nem kapunk meg”; „mint ismeretes, még nem jöttünk rá, vajon ő maga rendelkezik-e művekkel”; „éppen az ő tehetségességét, ami szilárd meggyőződése volt, nem fedezzük fel”; „nem jövünk rá, kinek maradhat fenn a tudása", stb.

Föltétlenül meg kell említenünk, hogy az élboly és a versenyzők - sajnos - többségének fölkészültsége között a különbség aggasztóan nagynak mutatkozott. Sokan ugyanis nemcsak egy-egy mondat, hanem olykor az egész szöveg értelmét illetően is csak a találgatásra hagyatkozhattak, s ez nem is mindig írható pusztán a szöveg nehézségének a rovására. Csak néhány példa: alii alio ex fonte praeceptores dicendi emanaverunt: „egyik is, másik is a szónoklás tanítóinak kútjából eredt”; „veteres scriptores artis”: „tapasztalt költőmesterek”; ut ceteros et se ipsum per se cognosceremus: „hogy a hátsók és mi magunk együtt tanuljunk”.

A teljes arpinói magyar csapat kiutazását az Emberi Erőforrások Minisztériuma NTP-TV-14-B-0001sz. pályázata tette lehetővé.

(A versennyel kapcsolatos további információk az abeljeno.elte.hu/arpino oldalon találhatóak.)

Az Ábel Jenő Országos Latin Tanulmányi Verseny 2015. február 6-i első, iskolai fordulóján 33 vidéki és 17 budapesti, azaz összesen 50 iskola 552 diákja versenyzett: 320-an a minores (Budapestről 174, vidékről 146) és 232-en a maiores (Budapestről 100, vidékről 132) kategóriában. A maiores kategória tételének címe „Vergilius munkamódszeréről”, a minoresé pedig „Ha két remete találkozik” volt. Az iskolákból 217 dolgozatot küldtek be, ebből 79-et a maiores (Budapestről 41, vidékről 38), 138-at a minores (Budapestről 75, vidékről 63) kategóriában. A döntő fordulóra 44 (26 vidéki és 18 budapesti) iskolából hívtunk be összesen 182 főt, a maiores kategóriában 79 (Budapestről 41, vidékről 38), a minores kategóriában 103 főt (Budapestről 50, vidékről 53), akik közül a megjelent 70 maior, 95 minor versenyző április 11-én az ELTE BTK-n mérhette össze tudását. 
A maiores kategória tételének címe „Amikor még nem voltak helyszínelők”, a minoresé pedig „A lófarok és a rómaiak" volt. A két forduló tételei honlapunkon, a http://abeljeno.elte.hu/ címen megtalálhatóak.

A következőkben bemutatjuk a versenyünkön elkövetett jellegzetes fordítási hibákat, általánosabb körű nehézségeket, a döntő fordulóra koncentrálva, hiszen az első forduló tételeinek buktatóit a tanár kollégák versenyzőik dolgozatait javítva már megismerhették.

A maiores kategória döntőjén örvendetesen kevés hiba adódott félreolvasásból vagy félreszótárazásból. A szótár címszavainak alapos áttanulmányozása terén azonban akadtak hiányosságok. A nyilvánvalóan 'ugyanis' értelemben álló enim fordítását többek a „mindenesetre” szóval próbálták megoldani, noha a szövegből kiviláglott, hogy a harmadik mondat magyarázatot füz az azt megelőzőhöz, a „mindenesetre” pedig leginkább csak megterheli a mondatfüzést. Meglepőbb ennél, hogy több versenyző is akadt, aki a cselekmény kiindulópontjául szolgáló mozzanatot, az új asszony feleségül vételét nem tudta megfejteni, mert a szótárban a novus szónál nem maradt meg az első jelentésnél, hanem tovább kutakodva bonyolultabbá tette a narratívát azáltal, hogy nem egyszerüen új, hanem szokatlan asszony „került a házhoz”. A vulnus fordítása során pedig az fordult elő, hogy a szótárban feltüntetett 'repedés [képé]' metaforikus használatot alkalmazták egy konkrét vulnus esetében. Így jött létre két-három olyan fordítás, melyben a kardot nem egy sebbe, hanem egy repedésbe szúrva találták meg a holttest felfedezői. Hasonló számban akadtak olyan dolgozatok, melyekben a megszólított bírákhoz intézett cogitate igealakot ('gondoljátok meg!') a cogitatus adverbiumának vélték - tehették ezt annál is inkább, mert a szótár külön lemmát szentel ennek a határozószónak -, s úgy értelmezték: 'megfontoltan'. Így persze szétesett a mondat, elveszítvén központi elemét, a főmondati állítmányt. Az igeneves szerkezetek közül többeknek gondot okozott a pariete cruentato ablativus absolutusi voltának felismerése. Néhány versenyző a dicitur caecus kezdetủ mondatban a passzív állítmányt úgy fordította, mintha aktív volna, így a nominativus cum infinitivo értelmét nem sikerült megfejteniük, s az „azt mondja a vak” magyar kifejezést alkották meg. A legtöbb sikertelenség kétségtelenül a következő mondathoz kapcsolódik: caecitatis miserae solacium est habere aliquam rem videntium (,a boldogtalan vakság vigasza az, ha bírják a látók valamely dolgát"). Bár a mondathoz lábjegyzetet füztünk, sok diáknak reménytelenül nehéznek bizonyult a videntium participium értelmezése. (Két példa a számos félrefordítás közül: „valamilyen módon látni ezt a tárgyat”, „az érzékelésnek valami más módját birtokolhatja”.) Ahogy a korábbi években is, most is akadtak versenyzők, akik nem figyeltek eléggé az elmesélt történet koherenciájára. Így az egyik magyarítás azt a képtelen jelenetet is tartalmazta, hogy „a vak ifjú nézegette a kardját”. Az apró stilisztikai csúszások közül figyelemre méltó a iudices „Bíró urak!”-kal való fordítása, ami inkább a magyar népmesék hangulatát idézi. Végigtekintve a dolgozatokon megállapíthatjuk, hogy az élmezőny és a többi versenyző teljesítménye között meglepően széles szakadék figyelhető meg. Örvendetes módon idén is akadt néhány olyan fordítás, mely szinte hibátlannak mondható.

A minores kategóriájában születtek csaknem hibátlan dolgozatok is, de úgy tűnik, a szöveg szinte minden versenyző számára tartogatott egy-két gonosz csapdát. Az első mondat menetét megszakító, uttal felvezetett mellékmondat számos diákot megzavart. Az egyszerü, hasonlítói jelentésű $u t$ kötőszó fordításaként előfordult az ut szinte minden használata, sőt olyan versenyző is akadt szép számmal, aki egyszerüen etnek olvasta („és ő maga is már sok tapasztalatot szerzett”). A fő problémát azonban az jelentette, hogy sokan nem ismerték fel a közbeszúrt mellékmondat előtti és utáni félmondat összefüggését, és nem sikerült a két félből szerves egészet kovácsolniuk. Szintén visszatérő hiba volt ugyanebben a mondatban az imparnak és dativusi vonzatának félreértelmezése (,az egész római hadsereg különböző volt”, , az összes római hadsereg között páratlan volt", „különb volt a rómaiak minden hadseregénél”). A dativusi vonzatok az admovit esetében is gondot okoztak: sokan vagy felcserélték a szereplőket („a gyenge lovat egy erős katonához vezette”), vagy szó szerinti és így magyartalan fordítást adtak („a sovány lónak izmos katonát vezetett”). A pugna kontextusidegen fordítása („ökölharcra hívták”, „ökölvívást követeltek”) nyilvánvalóan a fordítási rutin hiányával magyarázható. Ugyanide sorolható a natura jelentésével kapcsolatos bizonytalanság („a római hadseregek születése”). Szintén a rutintalanság magyarázhatja a szövegen végigvonuló universus 3 melléknévvel kapcsolatos értelmezési nehézségeket („ha a világegyetemben egy harcos küzdene a vágyaival”, „szakítsd le a világ lovainak farkát”, „a világmindenséggel egy csatában akartok küzdeni”). Ezzel szemben inkább figyelmetlenségre, az önellenőrzés hiányára utalnak azok a hibák, amelyek esetében a versenyző lecsapott a tő első szótári előfordulására, és 
nem gondolkodott tovább - ilyen volt pl. az equus nemének eltévesztése („két kancát a katonák szeme láttára magához húzott"). Ismét tapasztalható volt az élő újlatin lexikai ismeretek beszűrődése is, főleg a misit esetében („az erős lóhoz odadob egy vékony férfit”). Az in conspectum militum kifejezés esetében nem segített a lábjegyzet, így a versenyzők a szótárra és saját józan eszükre voltak utalva. Volt, aki vette az akadályt, volt, aki némiképp körülményesen, de közelítőleg helyesen adta vissza a jelentést („a katonák látókörébe”), mások a conspectus 3-ból indultak ki („tekintélyes katonák között”), vagy épp supinumra gyanakodtak („hogy pillantsák meg őket”). Ezúttal sem maradtak el a kultúrtörténeti háttérismeretek hiányosságaira visszavezethető hibák: így egyesek a Quintus praenoment is lefordították („Ötödik Sertorius”, sőt „V. Sertorius”), annak ellenére, hogy a bevezetőben találkozhattak a név teljes alakjával. Ugyanide sorolható a milites eius barbari félreértése, szintén a bevezetőben elrejtett rávezető információk dacára: sokan nem tudták elképzelni, hogyan kerülnének barbárok egy római hadvezér seregébe, ezért aztán megpróbálták átvitt értelemben magyarázni a melléknevet („tudatlan”, „műveletlen”, „kegyetlen”), vagy éppen őket tették meg ellenségnek. Örvendetes volt viszont a politikailag korrekt megfogalmazások megjelenése néhány dolgozatban („nem római származású katonái”).

A versenyen mindegyik, helyezést elért vagy kiemelt dicséretben részesülő tanuló az elismerő oklevél mellé könyvjutalmat is kapott, ily módon összesen 77 főt díjazhattunk. A könyvjutalmakat idén 14 kiadó nagylelkű felajánlása biztosította. A következő kiadóknak rójuk itt le hálás köszönetünket versenyünk lelkes és rendszeres támogatásáért: a Tinta, a Balassi, az Akadémiai, a Kairosz, a L'Harmattan, az Argumentum, a Gondolat, a Kalligram, a Holnap, az Atlantisz, a Scolar, a Mundus, a Lexika és a Szent István Társulat. Ezenkívül az Ókor című folyóirat szerkesztősége s kiadója, a Gondolat, a két kategória első három helyezettjének és tanáruknak egyéves előfizetést ajánlott fel. Köszönetünket nyilvánítjuk Szőke Ágnesnek, aki magánszemélyként nyújtott könyvtámogatást.

Továbbá a Magyar Nemzeti Múzeum főigazgatója, Csorba László a két kategória első 20 helyezettjének egy-egy tiszteletjegyet ajánlott fel, amely egy diák és egy szülő ingyenes belépésére jogosít fel, és amelyet az év végéig lehet a díjazottaknak felhasználniuk.

Végezetül szeretnénk köszönetet mondani minden latintanárnak és versenyző diáknak áldozatos munkájukért, az iskolák igazgatóinak a latinoktatás támogatásáért, a verseny szervezőbizottságának a sikeres lebonyolításért. Versenyünk pénzügyeinek és pályázati teendőinek intézéséért továbbá köszönet jár Adamik Bélának, az adminisztrációs feladatok lelkiismeretes ellátásáért és a honlap működtetéséért Nemes Júliának.

Összegzésképpen megállapíthatjuk, hogy versenyünk több évtizedes hagyományaihoz méltó módon zajlott le, és remélhetőleg fontos szerepet tud betölteni a középiskolai latinoktatás fennmaradásában, amely egyedül képviseli az ókori kultúrákat és nyelveket a középfokú oktatásban, és így döntő szerepet játszik a magyar ókortudomány utánpótlásának biztosításában.

Az Emberi Erőforrások Minisztériuma és az Ókortudományi Társaság

Ábel Jenő Latin Tanulmányi Versenyének végeredménye

2014/2015. tanév

\section{Maiores kategória}

I. helyezett

II. helyezett

III. helyezett

4. helyezett:

5. helyezett:
Perosa Sandra, a budapesti Veres Péter Gimnázium növendéke, tanára: Hőnich Orsolya, igazgató: Papp György

Csigó Ábel, a soproni Berzsenyi Dániel Evangélikus Gimnázium növendéke, tanára: Jakabné Csizmazia Eszter, igazgató: Tölli Balázs

Ehreth Réka, a budapesti ELTE Radnóti Miklós Gyakorló Gimnázium növendéke, tanára: Nagy Piroska, igazgató: dr. Molnár Katalin

Majoros Gabriella, a budapesti Baár-Madas Református Gimnázium növendéke, tanára: Marton Ágota, igazgató: Tombor László

Gera Anna, a szigetszentmiklósi Batthyány Kázmér Gimnázium növendéke, tanára: Nagy Judit és Virág Barnabás, igazgató: Kissné Hegedűs Éva 
6. helyezett: Gloviczki Ráhel, a váci Piarista Gimnázium növendéke, tanára: Pálfai Remig, igazgató: Futó Béla Sch. P.

7. helyezett: Kiss Nándor, a budapesti II. Rákóczi Ferenc Gimnázium növendéke, tanára: Jármi Viktória, igazgató: Magócs Éva

8. helyezett: $\quad$ Szilágyi Hanna, a budapesti Budai Ciszterci Szent Imre Gimnázium növendéke, tanára: Kudari Enikő, igazgató: Barlay Bence

9. helyezett: $\quad$ Kullai Ádám, a budapesti ELTE Radnóti Miklós Gyakorló Gimnázium növendéke, tanára: Nagy Piroska, igazgató: dr. Molnár Katalin

10. helyezett: Debreceni Luca, a budapesti Eötvös József Gimnázium növendéke, tanára: Imre Flóra, igazgató: Moss László

11. helyezett: $\quad$ Szemán Réka, a debreceni Svetits Katolikus Gimnázium növendéke, tanára: Géczy M. Erzsébet, igazgató: Bártfay Katalin

12. helyezett: Dobos Rozália, a budapesti Németh László Gimnázium növendéke, tanára: Juhász Sarolta, igazgató: Varga Attila

13. helyezett: Németh Flóra, a budapesti Fazekas Mihály Gyakorló Gimnázium növendéke, tanára: Péli Ágota, igazgató: Hámori Veronika

14. helyezett: Vágási Veronika, a budapesti Budai Ciszterci Szent Imre Gimnázium növendéke, tanára: Paksy Nóra, igazgató: Barlay Bence

15. helyezett: Szathury Bálint, a budapesti Piarista Gimnázium növendéke, tanára: Koós Levente, igazgató: Urbán József Sch. P.

16. helyezett: Losonci Blanka, a budapesti Balassi Bálint Nyolcévfolyamos Gimnázium növendéke, tanára: dr. Kiss Gáborné, igazgató: Farkas György

17. helyezett: $\quad$ Tankó Zita, a budapesti Budapesti Egyetemi Katolikus Gimnázium növendéke, tanára: Gilyén Mátyás, igazgató: Endrédi Józsefné

18. helyezett: $\quad$ Kubicsek Ferenc, a soproni Szent Orsolya Római Katolikus Gimnázium növendéke, tanára: Sztrókay Adél, igazgató: dr. Kovács András

19. helyezett: Kócziás Veronika, a budapesti Budai Ciszterci Szent Imre Gimnázium növendéke, tanára: Kudari Enikő, igazgató: Barlay Bence

20. helyezett: Kecskés Csoma, a budapesti Eötvös József Gimnázium növendéke, tanára: Imre Flóra, igazgató: Moss László

Kiemelt dicséretben részesült

Oszlács Enikö

Czakó Emese

Kiss Máté

Somjai Eszter

Balatoni Szilárd

Hoffer Dóra

Székely Kadosa

Koppány

Szirt Viktória

Kerti Anna Emese

Szajbély Anna

Vadon Bernadett

Papp Bertalan Péte

Jakab Kornél Bálint

Varga Eszter a budapesti Baár-Madas Református Gimnázium növendéke, tanára: Marton Ágota a budapesti Budai Ciszterci Szent Imre Gimnázium növendéke, tanára: Paksy Nóra a debreceni Medgyessy Ferenc Gimnázium növendéke, tanára: Kocsis Márta a győri Kazinczy Ferenc Gimnázium növendéke, tanára: Schnur Mátyás

a budapesti Piarista Gimnázium növendéke, tanára: Koós Levente

a budapesti Budapest Fasori Evangélikus Gimnázium növendéke, tanára: CalligarisHorváth Erika

a debreceni Tóth Árpád Gimnázium növendéke, tanára: Biczóné Porcsin Judit

a budapesti Patrona Hungariae Gimnázium növendéke, tanára: Gazdag Gemma a váci Piarista Gimnázium növendéke, tanára: Pálfai Remig a budapesti Fazekas Mihály Gyakorló Gimnázium növendéke, tanára: Péli Ágota a budapesti Budai Ciszterci Szent Imre Gimnázium növendéke, tanára: Paksy Nóra

a pannonhalmi Bencés Gimnázium növendéke, tanára: Csertán Judit

a tatai Református Gimnázium növendéke, tanára: dr. Horváth Zsoltné

a szigetszentmiklósi Batthyány Kázmér Gimnázium növendéke, tanára: Nagy Judit, Virág Barnabás 
Edöcs Johanna a budapesti Budapest Fasori Evangélikus Gimnázium növendéke, tanára: CalligarisHorváth Erika

Matus Mercédesz a szekszárdi Garay János Gimnázium növendéke, tanára: Töttős Gábor

Berky Eszter a székesfehérvári Ciszterci Szent István Gimnázium növendéke, tanára: Berta Annamária

Dicséretben részesült

Szlovicsák Béla

Varga Luca

Kocsár Carlo

Benedek

Pálúr Judit

Balla Júlia

Závoti Olivér

Tüzes Ágoston

Boa Patrik

Sirák Márton

Lovasi Nikolett

Dávid Debóra

Nossack Hanna

Facskó Benedek a pannonhalmi Bencés Gimnázium növendéke, tanára: Csertán Judit a budapesti Budai Ciszterci Szent Imre Gimnázium növendéke, tanára: Kudari Enikő a debreceni Csokonai Vitéz Mihály Gimnázium növendéke, tanára: Molnárné Kocska Judit a budapesti Baár-Madas Református Gimnázium növendéke, tanára: Marton Ágota Flóra

a szigetszentmiklósi Batthyány Kázmér Gimnázium növendéke, tanára: Nagy Judit a budapesti Veres Péter Gimnázium növendéke, tanára: Hőnich Orsolya

a budapesti Budapest Fasori Evangélikus Gimnázium növendéke, tanára: CalligarisHorváth Erika

a soproni Berzsenyi Dániel Evangélikus Gimnázium növendéke, tanára: Jakabné Csizmazia Eszter

a székesfehérvári Ciszterci Szent István Gimnázium növendéke, tanára: Berta Annamária

a debreceni Medgyessy Ferenc Gimnázium növendéke, tanára: Kocsis Márta az orosházi Táncsics Mihály Gimnázium növendéke, tanára: Mikulás Rolandné a budapesti Balassi Bálint Nyolcévfolyamos Gimnázium növendéke, tanára: Faragó Ildikó

a budapesti Veres Péter Gimnázium növendéke, tanára: Hőnich Orsolya

\section{Minores kategória}

I. helyezett

II. helyezett

III. helyezett

4. helyezett:

5. helyezett:

6. helyezett:

7. helyezett:

8. helyezett:

9. helyezett:

10. helyezett:
Tüz Boglárka, a budapesti ELTE Apáczai Csere János Gyakorlógimnázium növendéke, tanára: Jankovics László, igazgató: Munkácsy László

Avramucz Tamás, a kecskeméti Piarista Gimnázium növendéke, tanára: Acél Zsolt Sch. P., igazgató: Nagy Attila Sch. P.

Kovordányi Anna, a budapesti Budapest Fasori Evangélikus Gimnázium növendéke, tanára: Calligaris-Horváth Erika, igazgató: Hajdó Ákos

Szilvágyi Lilla, a budapesti Budapest Fasori Evangélikus Gimnázium növendéke, tanára: Calligaris-Horváth Erika, igazgató: Hajdó Ákos

Dáné Bernadett, a budapesti Budapest Fasori Evangélikus Gimnázium növendéke, tanára: Calligaris-Horváth Erika, igazgató: Hajdó Ákos

Máté Csaba, a budapesti Piarista Gimnázium növendéke, tanára: Koós Levente, igazgató: Urbán József Sch. P.

Szikora Luca, a szentendrei Ferences Gimnázium növendéke, tanára: Zeke Szilárd, igazgató: P. Frész Timóteus

Orbán Emese, a budapesti Budapest Fasori Evangélikus Gimnázium növendéke, tanára: Calligaris-Horváth Erika, igazgató: Hajdó Ákos tanára: dr. Czeglédi Sándor, igazgató: Kádár Péter

Schell Réka, a budapesti Budai Ciszterci Szent Imre Gimnázium növendéke, tanára: Gáll Zsófia, igazgató: Barlay Bence
Tóth Brigitta, a hódmezővásárhelyi Bethlen Gábor Református Gimnázium növendéke, 
11. helyezett:

12. helyezett:

13. helyezett:

14. helyezett:

15. helyezett:

16. helyezett:

17. helyezett:

18. helyezett:

19. helyezett:

20. helyezett:
Pete Miklós, a debreceni Svetits Katolikus Gimnázium növendéke, tanára: Géczy M. Erzsébet, igazgató: Bártfay M. Zsuzsanna

Seress Iván, a budapesti ELTE Apáczai Csere János Gyakorlógimnázium növendéke tanára: Jankovics László, igazgató: Munkácsy László

Balázs Beatrix, a budapesti Városmajori Gimnázium növendéke, tanára: Zaránd Kinga, igazgató: Szebedy Tas

Kiss Tamara, a soproni Berzsenyi Dániel Evangélikus Gimnázium növendéke, tanára: Jakabné Csizmazia Eszter, igazgató: Tölli Balázs

Malczanek Orsolya, a budapesti Patrona Hungariae Gimnázium növendéke, tanára: Csermely M. Irén, igazgató: Rubovszky Rita

Grósz Anna, a győri Kazinczy Ferenc Gimnázium növendéke, tanára: Csonka István, igazgató: Németh Tibor

Endrédy Balázs, a budapesti Budai Ciszterci Szent Imre Gimnázium növendéke, tanára: Gáll Zsófia, igazgató: Barlay Bence

Dénes Laura, a budapesti Budapesti Egyetemi Katolikus Gimnázium növendéke, tanára: Devich Dénes, igazgató: Endrédi Józsefné

Hollókövi Stefánia, a szentendrei Református Gimnázium növendéke, tanára: dr. Török Márta, igazgató: Földi János

Tirol Zsófia, a szentendrei Református Gimnázium növendéke, tanára: dr. Török Márta, igazgató: Földi János

Kiemelt dicséretben részesült

Köröshegyi Benedek a budapesti Piarista Gimnázium növendéke, tanára: Koós Levente

Velkey Vince a budapesti Piarista Gimnázium növendéke, tanára: Koós Levente

Végh Zsófia a budapesti Budapest Fasori Evangélikus Gimnázium növendéke, tanára: CalligarisHorváth Erika

Fodor Bertalan a budapesti Balassi Bálint Nyolcévfolyamos Gimnázium növendéke, tanára: Kaszab László

Léta Noémi a budapesti Patrona Hungariae Gimnázium növendéke, tanára: Csermely M. Irén

Szász Keve a váci Piarista Gimnázium növendéke, tanára: Király Bálint

Dobó Sára Borbála a szentendrei Református Gimnázium növendéke, tanára: dr. Török Márta

Budaházy Csenge a szigetszentmiklósi Batthyány Kázmér Gimnázium növendéke, tanára: Virág Barnabás

Szénási Dóra a szentendrei Református Gimnázium növendéke, tanára: dr. Török Márta

Tóth Imola Anna a budapesti Budai Ciszterci Szent Imre Gimnázium növendéke, tanára: Paksy Nóra

Kollár Dorottya a budapesti Városmajori Gimnázium növendéke, tanára: Zaránd Kinga

Solti Sára a gödöllői Török Ignác Gimnázium növendéke, tanára: Vargáné Balogh Katalin

Módi Sára Orsolya a budapesti Németh László Gimnázium növendéke, tanára: Juhász Sarolta

Pigler Donát

a budapesti Piarista Gimnázium növendéke, tanára: Koós Levente

Frank Tamás

a budapesti Budai Ciszterci Szent Imre Gimnázium növendéke, tanára: Illyés Erika

Frank Ágoston a soproni Berzsenyi Dániel Evangélikus Gimnázium növendéke, tanára: Jakabné Csizmazia Eszter

Czékmán Flóra a székesfehérvári Ciszterci Szent István Gimnázium növendéke, tanára: Berta Annamária

Mátyási Klaudia a szigetszentmiklósi Batthyány Kázmér Gimnázium növendéke, tanára: Virág Barnabás

Rákos Réka a debreceni Svetits Katolikus Gimnázium növendéke, tanára: Géczy M. Erzsébet Bihari Máté a budapesti Budai Ciszterci Szent Imre Gimnázium növendéke, tanára: Illyés Erika 
Dicséretben részesült

Granc Klára

Kalabay László

Jancsovics Janka

Gurabi Anna

Török Emma

Énekes Dávid

Dorotovics Zsuzsanna

Peitl Berta

Tar Péter

Szilágyi Margaréta

Katona Szibilla

Léta Jolán

Tóth Johanna Eszter

Jalsovszky Janka

Aladics Réka

Laczó Brigitta

Földváry Levente

Varga Sára

Nyull Fanni

Kovács Kinga a szigetszentmiklósi Batthyány Kázmér Gimnázium növendéke, tanára: Virág Barnabás

a budapesti Budai Ciszterci Szent Imre Gimnázium növendéke, tanára: Kudari Enikő

a budapesti Budapest Fasori Evangélikus Gimnázium növendéke, tanára: Tasnádi Zsuzsanna

a budapesti Budapest Fasori Evangélikus Gimnázium növendéke, tanára: Tasnádi Zsuzsanna

a szentendrei Református Gimnázium növendéke, tanára: dr. Török Márta

a szekszárdi Garay János Gimnázium növendéke, tanára: dr. Gesztesi Enikő

a makói József Attila Gimnázium növendéke, tanára: Palotás György

a soproni Szent Orsolya Római Katolikus Gimnázium növendéke, tanára: Sztrókay Adél

a debreceni Tóth Árpád Gimnázium növendéke, tanára: Burai Erzsébet a budapesti Patrona Hungariae Gimnázium növendéke, tanára: Gazdag Gemma a hódmezővásárhelyi Bethlen Gábor Református Gimnázium növendéke, tanára: dr. Czeglédi Sándor

a budapesti Patrona Hungariae Gimnázium növendéke, tanára: Csermely M. Irén a szentendrei Református Gimnázium növendéke, tanára: dr. Török Márta a budapesti Városmajori Gimnázium növendéke, tanára: Zaránd Kinga a pécsi Ciszterci Rend Nagy Lajos Gimnáziuma növendéke, tanára: László Levente a budapesti Patrona Hungariae Gimnázium növendéke, tanára: Gazdag Gemma a váci Piarista Gimnázium növendéke, tanára: Király Bálint a soproni Berzsenyi Dániel Evangélikus Gimnázium növendéke, tanára: Jakabné Csizmazia Eszter

a budapesti II. Rákóczi Ferenc Gimnázium növendéke, tanára: Kukucskáné Szalontai Erika

a budapesti Városmajori Gimnázium növendéke, tanára: Zaránd Kinga 



\title{
JUHÁSZ ERIKA
}

\section{BESZÁMOLÓ A MAGYAR BIZANTINOLÓGIAI TÁRSASÁG 2014/2015. ÉVI TEVÉKENYSÉGÉRÖL}

\begin{abstract}
A Magyar Bizantinológiai Társaság 2014 második félévében közreműködött az Eötvös József Collegiumban megrendezett Byzanz und das Abendland III. nemzetközi konferencia (november 24-28.) megszervezésében. Bár a konferencia francia (Gallica) és olasz nyelvű (Italica) szekcióiban is több bizantinológiai tárgyú előadás hangzott el, mindemellett a Bizánc történetével, utóéletével, valamint a görög források papirológiai, paleográfiai, kodikológiai szempontú vizsgálatával kapcsolatos kutatások bemutatására többnyire a Graeca szekció keretében (november 25-27-én) került sor. A konferencián, melyet több könyvbemutató is színesített, az alábbi előadásokat hallgathatta meg az érdeklődő közönség.
\end{abstract}

2014. november 24 .

Egedi-Kovács Emese: Au carrefour de diverses cultures : le roman de Barlaam et Joasaph dans le manuscrit d'Iviron ( $\left.N^{\circ} 463\right)$

Palágyi Tivadar: « Car croi en Diu si feras bien! » Polémique religieuse dans l'Expeditio Persica de Georges de Piside (VII siècle) et dans l'Eracle de Gautier d'Arras (XII' siècle)

2014. november 25

Carolina Cupane: La visita di Partonopeu a Constantinopoli. Un modello di ricezione letteraria?

Romina Luzi: Les romans paléologues : à la charnière de plusieurs traditions

Ellen Söderblom Saarela: La fonction de Byzance dans le roman français du XII siècle

Zuzana Černáková: The Metamorphoses of the Representation of Byzantine General Tatikios in Historiography and Epic of Twelfth-century France

Szegedi Eszter: La fortuna di Procopio di Cesarea nella librettistica italiana del Sei e Settecento

Renzo Tosi: Riprese di proverbi classici nei romanzi bizantini

Peter Schreiner: Geschichte und Geschichten aus dem Osten. Die frühe westliche Geschichtsschreibung und Byzanz (plenáris előadás)

Francesco D'Aiuto: Byzantine Inscriptions from Rome: A Reconsideration

Filippo Ronconi: Linfluence des contrastes entre le patriarcat de Constantinople et les papes sur la composition de la Bibliothèque de Photius. Remarques préliminaires

Hermann Harrauer: Gefesselt von Amuletten (plenáris előadás)

John Tolan: Graeculus dixit: Byzantium as Intermediary between Islam and Latin Europe?

Nicolas Drocourt: Quelques aspects relatifs au milieu naturel dans les relations diplomatiques entre Byzance et l'Occident chrétien (VIII ${ }^{e}$ XII ${ }^{e}$ s.)

Könyvbemutató: Jacqueline de Romilly - Monique Trédé: Az ógörög nyelv szelleme. TypoteX, Budapest 2014. Ford.: Vargyas Brigitta; szerk.: Horváth László.

2014. november 26 .

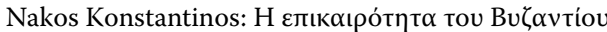

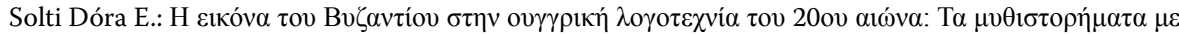

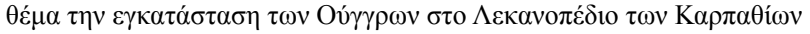

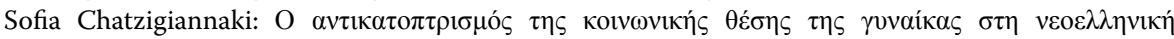

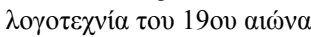




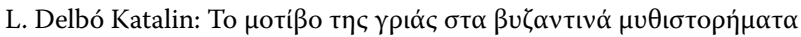
Mayer Gyula: Zur Sprache des Archimedes

Mészáros Tamás: Once upon a Time in the East: Moravcsik vs. Darkó

Srđan Pirivatrić: Byzantine-Hungarian Relations in 1162-1167 and the Deposition of Serbian Grand Župan Desa

Tóth Iván: Investigations into Kritobulos' Idea of History

Christian Gastgeber: Chronicon Paschale: Ein Codex unicus und lauter Probleme

Fabian Schulz: Die Tuskulanischen Fragmente und ihr Wert für die Rekonstruktion des Malalas-Texts Juhász Erika: Olympiaden in der Osterchronik

Sergei Mariev: John of Antioch and John Malalas: Limits and Advantages of the 'Open Text' Approach Martin Hurbanic: A Neglected Note to the Naval Defense of Constantinople during the Avar Siege: the Position of Skafokaraboi in the Golden Horn

Vratislav Zervan: Biblische Typologie in der Christlichen Topographie und in Chronicon Paschale

Könyvbemutató: Juhász Erika (szerk.): Byzanz und das Abendland II. Studia Byzantino-Occidentalia. Eötvös József Collegium, Budapest 2014.

2014. november 27.

Vlastimil Drbal: Die byzantinischen Pilgerstätten im Nahen Osten aus der Sicht der Theorien der heiligen Orte von Mircea Eliade und Victor Turner: "Zentrum der Welt" vs. „The Center out There”

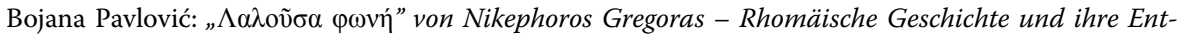
stehung

Andrea Cuomo: Byzanz und das Morgenland. Sprachliche Begegnungen mit den Osmanen in der Paläologenzeit

Ekler Péter: Oratio de Sacramento Eucharistiae. Epistola ad Graecos. (Greek and Byzantine Authors and Augustinus Moravus Olomucensis)

A konferencia záró ülésszakán a korábbi évek gyakorlatának megfelelően magyar és külföldi egyetemi hallgatók számoltak be saját kutatásaikról idegen nyelven:

Giulia Rossetto: Der Corpus der physikalischen Abhandlungen des Aristoteles in den Codex Vind. Phil. gr. 100: einige Überlegungen

Rózsa Márton: The Informal Networks of the Byzantine Government and Society in the Early Komnenian Period: the Case of John Melidones

Szikora Patrícia: An Interpretation of Similes in Corippus' Poem In laudem Iustini

Szegvári Zoltán: A Byzantine Rotulus about Exorcism. The Supplementum Graecum 116 of the Austrian National Library

Kovács István: Teaching Rhetoric in the Palaiologos Era

Ivan Lábaj: The 2nd Dialogue of Sambucus' De imitatione Ciceroniana

Marek Šibal: Miscellanea Philologica et Grammatica in the Manuscript Vind. Phil. Gr. 172 from the Collection of Johannes Sambucus

Tóthné Mihálykó Ágnes: Christ and Charon: the PGM P 13 in Context

Az elhangzott előadások szerkesztett változata idegen nyelvủ konferenciakötetben jelenik meg. A konferenciával párhuzamosan Paolo Odorico, a párizsi Centre d’Études Byzantines, Néo-helléniques et Sud-est Européennes (EHESS) igazgatója tömbösített szemináriumot tartott a Bollók János Klasszika-filológia mủhely tagjainak Introduction into Byzantinology címmel. 
2015 első félévében a Társaság havi rendszerességgel tartott felolvasóüléseket neves hazai és külföldi előadók részvételével.

2015. február 16.

Mark Janse (Ghent University; All Souls College, Oxford): The Survival of Cappadocian Greek. Language, Religion and Identity in Ottoman Cappadocia and Beyond

2015. március 2 .

Bálint Csanád (MTA Bölcsészettudományi Kutatóközpont): A nagyszentmiklósi kincs és Bizánc

2015. május 5.

Anastasia Maravela (Universitetet i Oslo): “School texts” from Western Theban Monasteries: Classical Culture and Education in Late Antique Monastic Settings in Egypt

2015. május 26.

S. E. Dimitris Yannakakis (Görögország magyarországi nagykövete): Aspects of Identity in the Byzantine Empire

2015. június 8 .

Hermann Harrauer (nyugalmazott professzor: Universität Wien; Papyrussamlung der Österreichischen Nationalbibliothek): Austern als Luxusspeise in Papyri

A Társaság 2015. február 23-án tisztújító közgyủlést tartott. Az újonnan megválasztott Elnökség tagjai: elnök: Bálint Csanád; titkár: Juhász Erika; elnökségi tagok: Farkas Zoltán, Horváth László, Mészáros Tamás, Nakos Konstantinos, Solti Dóra, Takács Miklós, Zsupán Edina. 



\author{
GÁBOR DÁVID
}

\title{
BESZÁMOLÓ A SEC COLLEGIUM HUNGARICUM X. ORSZÁGOS KONFERENCIÁJÁRÓL
}

\author{
(Szeged, 2015. május 20-21.)
}

2015. május 20-21-én a Szegedi Tudományegyetem Bölcsészettudományi Karán a Klasszika-Filológia és Neolatin Tanszék szervezésében immár tizedik alkalommal került megrendezésre a SEC Collegium Hungaricum országos diákkonferenciája. A jubileumi alkalmat a Kar dékánja, Prof. Dr. Szajbély Mihály nyitotta meg. A konferenciát Dr. Ritoók Zsigmond professor emeritus (ELTE), a Magyar Tudományos Akadémia rendes tagja is megtisztelte jelenlétével, $\mathrm{s}$ a bölcsészettudomány mai állására reflektálva a megértésről és értelmezésről mint a társadalom működéséhez nélkülözhetetlen folyamatokról beszélt. Varga Ákos a Bölcsészettudományi Kar HÖK-elnöke köszöntőjében üdvösnek nevezte a hasonló kezdeményezéseket, és jövőbeli támogatásáról biztosította a konferenciát.

Az első nap Dr. Kasza Péter elnöklésével egy szekciót hallgathattunk meg öt előadóval: Vámos Violetta a Pázmány Péter Katolikus Egyetem Tres Montes tagintézményének képviseletében Vörösmarty Zalán futása című eposza szerelmi szálának antik előzményeiről tartott előadást, különös tekintettel Ovidius $M e$ tamorphosesének eddig nem tárgyalt lehetséges hatására. Horváth Balázs, az Eötvös Collegium Bollók János Officinájának tagja az Árpád-kori zágrábi egyházmegye sacramentariumainak regensburgi kapcsolatát feltáró kutatásáról számolt be. Gábor Dávid (PPKE) Petőfi Jövendölés és A helység kalapácsa című költeményeinek horatiusi előzményeiről, motívumainak megjelenéséről, illetve azok használatáról beszélt előadásában. Czeti István (EC) egy Guarino által Mátyásról megörökített anekdota kapcsán fejtegette az idézett, antik orvostudományi-fiziognómiai elképzelésekből átöröklődött vélekedés lehetséges forrásait Mire utalhatott Mátyás király? című előadásában. A nap zárásaként Rédey János (EC) Agyich István Saeculumának antik előzményeiröl tartott elöadást.

A második napon két szekcióban szintén öt-öt előadót hallhattunk. A délelőtti, Dr. Pataki Elvira által vezetett előadás-sorozatot Kapi Péter a Szegedi Tudományegyetem Officina Försteriana műhelyének képviseletében kezdte. Előadásában Pomponius Mela De Chorographia című munkájának keltezésével kapcsolatos problémákat ismertetett. Ezután Kassai Gyöngyi (EC) az Aeneis IV. énekének Dryden-féle angol fordításáról, különösen a shame és a fame motívum szerepéről számolt be, s hívta fel a figyelmet a hangsúlyok tudatos áthelyezésére. Öt követte Móréh Judit (PPKE), aki Poseidippos csodás gyógyulás-tematikájú ciklusát, a Iamatikát közelítette meg az az irónia eszközének tudatos alkalmazása felől. Náday Ádám (SZTE) Pseudo-Aurelius Victor Origo gentis Romanae című művének stilometriai elemzéséről, annak eredményeiről, valamint ezen eljárás klasszikus szövegekre történő alkalmazhatóságáról beszélt. Kárpáti András Dániel (PPKE) Poseidón „kék” haja? címmel a görögök színérzékeléséről beszélt, egészen pontosan a kyaneos színnév közelebbi meghatározására, illetve a szó időbeli jelentésváltozásának felderítésére tett kísérletet.

A délutáni szekciót, amelyen az elnök Dr. Nagyillés János volt, Pártay Kata (EC) kezdte, aki az Emberi fejlődés Euripidés Hiketidesében címmel tartott előadásában számolt be eredményeiről, különös tekintettel a Théseus kifejtette nézetnek a darabba való illeszkedéséről. Zsótér Szabolcs (SZTE) Lukianos és a szkíták - a görög identitás kérdése a II. században címmel beszélt a szerző szkíta tematikájú dialógusait felhasználva a paideia fogalmáról és identitásteremtő szerepéről, a görög polihisztor önmeghatározásáról, a szkítákkal kapcsolatos felfogások pozitív és negatív aspektusairól. Vincze Judit (EC) Achilleus Tatios regényének képleírásait, illetve azoknak a regény cselekményére gyakorolt szerepét, annak egyes elemeit hangsúlyozó hatását vizsgálta. Tuhári Attila (PPKE) Terentius Hecyra című komédiájának metatheátrális utalásairól, a látszat, valóság problematikájáról tartott előadást. Végül Harcz Klaudia (SZTE) az ovidiusi Halieutica szerzőségének 
kérdését boncolgatta, a mű szókincsének és párhuzamainak vizsgálatával csatlakozva Filippo Capponi korábbi kutatásaihoz.

A konferenciát a szegedi Klasszika-Filológia és Neolatin Tanszék vezetője, Dr. Nagyillés János zárta, aki beszédében köszönetet mondott az előadóknak, valamint a találkozó zökkenőmentes lebonyolításáért felelős szervezőknek. Külön örömét fejezte ki a növekvő érdeklődés miatt, és kifejezte abbéli reményét, hogy a következő évi, a Pázmány Péter Katolikus Egyetemen tartott esemény hasonló sikerrel zárul. A konferencia zárásaként Epiktétos gondolatával búcsúzott a résztvevőktől, amelyet a legjobban talán így foglalhatunk össze: Quidquid agis, prudenter agas et respice finem.

A hagyományokhoz híven az eseményen elhangzott előadások konferenciakötetben is megjelennek. 